\title{
Die 2020-direkte vertaling in Afrikaans: Waarom en hoe?
}

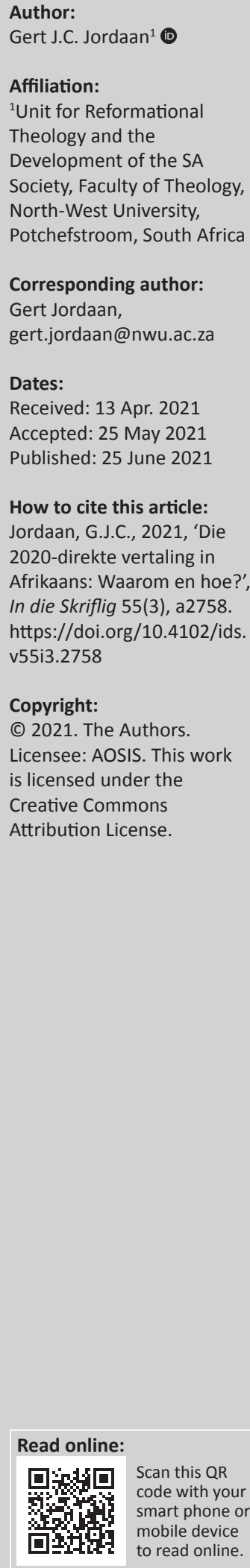

The $\mathbf{2 0 2 0}$ direct translation into Afrikaans: Why and how? The Bible Society of South Africa's commission that the new 2020 translation of the Bible into Afrikaans should be soundly source-text orientated and at the same time easy to understand, set a difficult task to the translators. The 2020 translators would have to dig deep to make these two almost opposing goals meet. The ways by which the translators eventually put their commission into practice, was investigated in this article. The method of investigation was to inspect the decisions of the translators' steering committee about how they planned to execute the commission they received from the Bible Society, and to test their decisions to its execution in practical examples from the 2020 translation itself. The investigation brought to light that the translators' success in the execution of their task, to a large extent, resulted from the fact that they, from the outset, made a clear distinction between the linguistic characteristics and the textual characteristics of both the source and the reception language. This enabled them to make a directly reflecting type of translation without giving way to either formal equivalence or dynamic equivalence. The translators decided not to translate into modern terms typical historic-cultural matters such as measures and weights, currencies and military ranks. By retaining the Hebrew and Greek terms, they tried to conserve the local colour of the source text and to provide a historical credibility to the translation. Moreover, the language and linguistic register of the translation was brought into line with a pre-identified target audience thus contributing to the dignity of the translation text and, simultaneously, making sure that it would be easily understood.

Contribution: The investigation led to the conclusion that the translators rather successfully dealt with the difficult task that the Bible Society had put before them. They made every effort to present their readers with a directly reflecting type of translation in a neat, stylistically meticulous and clear Afrikaans. Therefore, readers can receive this new contribution to the treasure of Afrikaans Bible translations with gratitude, and use it freely as a welcome addition to the already existing translations.

Keywords: 2020-translation; translators; objection scripts; Bible Society of South Africa; pilot committee.

\section{Inleiding en historiese aanloop}

Ná die verskyning van die 1983-vertaling van die Bybel in Afrikaans is daar by verskeie sinodes van die Gereformeerde Kerke in Suider-Afrika (GKSA) beswaarskrifte oor hierdie vertaling ingedien (bv. Acta 1991:128 art. 14; 2009:98 art. 13.2). Nie een van die beswaarskrifte kon egter slaag nie, want, soos die sinodes telkens bevind het, was die besware die gevolg van 'n verkeerde verwagting van die 1983-vertaling. Die beswaardes het verwag dat die 1983-vertaling die bronteks op 'n letterlik konkordante manier byna woord vir woord moet weergee, soos die 1933/1953-vertaling, maar net in eietydse Afrikaans.

Daarmee het die beswaardes die eiesoortige aard en doel van die 1983-vertaling misgekyk. Die 1983-vertaling het immers ' $n$ redelik dinamies ekwivalente aanslag gehad wat daarop gerig was om die bedoeling van die teks in maklik leesbare, duidelike en goed verstaanbare Afrikaans aan die leser oor te dra. Sedert 1983 het die kerke dus die voordeel van twee Afrikaanse vertalings gehad - elk met 'n eie aard en doel: die 1933/1953-vertaling wat op die woorde van die bronteks gefokus is, en die 1983-vertaling wat op die bedoeling van die bronteks gefokus is. Met die nodige onderskeiding kon hierdie twee vertalings met groot vrug naas mekaar in die kerke gebruik word.

Intussen het daar by kerke ' $n$ behoefte aan 'n derde Afrikaanse vertaling van die Bybel ontstaan. Dit het gekom vanuit besware dat die taalgebruik in die 1933/1953-vertaling verouderd is en 'n tweede hersiening nodig het. In reaksie hierop het die 1991-Sinode van die GKSA besluit dat, in 
plaas van 'n tweede hersiening, oorweging aan 'n nuwe formeel korrespondente vertaling van die Bybel in hedendaagse Afrikaans geskenk moet word (Acta 1991:131-133). Hierdie gedagte is in 1996 aan die Kerklike Advieskomitee van die Bybelgenootskap van Suid-Afrika voorgelê, en die Bybelgenootskap het onderneem om die moontlikheid en wenslikheid van so 'n vertaling te ondersoek (Acta 1997:123-124).

Die Bybelgenootskap het die aangeleentheid in die daaropvolgende paar jaar deeglik ondersoek deur uitgebreide navorsing te doen, 'n landwye markopname van stapel te stuur en verskeie simposium-gesprekke te voer. Hieruit het dit geblyk dat so 'n vertaling beslis wenslik is. Die gedagte van ' $n$ bronteksgeoriënteerde vertaling is verder ondersteun deur 'n nuwe wêreldwye tendens in Bybelvertaling dat die bronteks duidelik in die vertaling weerspieël moet word (vgl. De Wet 2020:1012). Hierdie vertaaltipe kan 'n direk weerspieëlende vertaling genoem word (vgl. Floor 2021). Wat veral in die nuwe vertaalkunde voorop staan, is dat die vertaling moet laat blyk dat die teks nie in die huidige tyd nie, maar 2000-3000 jaar gelede geskryf is. Die vertaling moet as 'n outentieke stem uit die verlede na die leser toe oorkom.

Die afloop van hierdie ondersoek was dat die Bybelgenootskap op versoek van die Kerklike Advieskomitee op 17 Februarie 2005 besluit het om met so ' $n$ vertaling in Afrikaans te begin (Bybelgenootskap van Suid-Afrika: Kerklike Advieskomitee [KABA] 2005:5, art 5; vgl ook De Wet 2020:1010). Die begeleidingskomitee wat vir die projek aangewys is, het op 15 September 2005 die vertaalopdrag en -proses geformuleer en goedgekeur (Bybelgenootskap van Suid-Afrika: Loodskomitee vir Direkte Bybelvertaling in Afrikaans [Loodskomitee] 2005).

\section{Vertaalopdrag}

Die vertaalopdrag is soos volg geformuleer: 'Skep 'n goed verstaanbare, bronteksgeoriënteerde Afrikaanse vertaling wat bedoel is vir voorlesing en gebruik in eredienste, asook virkategese, Bybelstudieen privaatgebruik'(Bybelgenootskap van Suid-Afrika: Loodskomitee vir Direkte Bybelvertaling in Afrikaans [Loodskomitee] 2005).

Op die oog af lyk dit na 'n moeilike en haas onhaalbare opgawe om tegelyk 'n bronteksgeoriënteerde sowel as 'n maklik verstaanbare vertaling die lig te laat sien. Indien die vertaler noukeurig by die bronteks wil hou, moet daar immers aan verstaanbaarheid ingeboet word en aan die ander kant vereis ' $n$ maklik verstaanbare vertaling dat daar van die bronteks af weg beweeg moet word (vgl. Du Plooy 2020:1033). Die 2020-vertalers het egter die opdrag aanvaar en probeer om dit op werkbare wyse uit te voer. Hieronder volg ' $n$ analise van hoe die vertaalopdrag deur hulle vertolk is, asook 'n uiteensetting en evaluering van hoe die opdrag in die praktiese proses van die 2020-Afrikaanse Bybelvertaling tot uitvoer gebring is.

\section{Bronteksgeoriënteerd}

Ten eerste word die vertaling as bronteksgeoriënteerd getipeer. Die bronteks wat deur vertalers gebruik moet word, veral vir die vertaling van die Nuwe Testament, is al vir meer as 'n eeu lank in die spervuur. Wanneer ' $n$ vertaling dus as bronteksgeoriënteerd voorgehou word, is die eerste vraag wat opduik die volgende: Watter bronteks word bedoel? Tweedens moet die term -georiënteerd verduidelik word: Wat is die verhouding tussen die bronteks en die ontvangertaal in so 'n vertaling?

\section{Die bronteks wat gebruik is}

\section{Die bronteks vir vertaling van die Ou Testament}

Die basisteks vir die vertaling van die Ou Testament was die vierde uitgawe van Biblia Hebraica Stuttgartensia $\left(\mathrm{BHS}^{4}\right)$, uitgegee deur die Deutsche Bibelgesellschaft Stuttgart in 1990. Dit is die jongste uitgawe van die eerste Biblia Hebraica Stuttgartensia (BHS) (1977) wat vir die 1983-vertaling gebruik is. Die teks van die BHS berus grootliks op die Codex Leningradensis, 'n manuskrip wat inderwaarheid min verskil van die sogenaamde Blomberg-Bybel, die teksuitgawe van die Ou Testament waaruit die 1933/1953-vertaling gedoen is (Van Rooy 2020a:914-920). Wat die Ou Testament betref, is daar dus weinig verskille tussen die bronteks wat onderskeidelik vir die 1933/1953-, 1983- en 2020-vertalings gebruik is.

Die 2020-vertalers het so ver moontlik getrou by die teks van die BHS gehou. Soms, waar die teks van die $\mathrm{BHS}^{4}$ wel probleme opgelewer het, het die vertalers egter eklekties te werk gegaan en ander lesings gevolg. Waar afwyking van die $\mathrm{BHS}^{4}$ nodig was, is dit met deeglike motivering gedoen en is in voetnote aangedui op watter getuies die vertaling berus (Van Rooy 2020a:926).

\section{Die bronteks vir vertaling van die Nuwe Testament}

Vir die vertaling van die Nuwe Testament is die vierde gekorrigeerde uitgawe van The Greek New Testament van die United Bible Societies ${ }^{1}$ van 1994 (UBS $^{4 \text { corr }}$ ) as basisteks gebruik. Die UBS ${ }^{4 c o r r}$ is die jongste van 'n reeks uitgawes van die UBSteks van die Griekse Nuwe Testament sedert 1966. Die 1983-vertaling het op die derde uitgawe van 1975 berus $\left(\mathrm{UBS}^{3}\right.$ ) wat basies dieselfde teks as UBS ${ }^{4 c o r r}$ bevat. Die UBSteks, hoewel merendeels klein en onbenullig, verskil op baie plekke van die Textus Receptus wat as basisteks vir die 1933/1953-vertaling gedien het (Jordaan 2009:174).

Die UBS ${ }^{4 c o r r}$-teks is egter nie bloot op die voetspoor gevolg nie. Uit die staanspoor het die Loodskomitee (2005: punt 2.2.1) vir vertaling besluit dat, waar nodig, alternatiewe lesings gevolg kan word. Gevolglik het die vertalers op enkele plekke op goeie gronde van die UBS4-teks afgewyk (Jordaan 2020:949952). In Openbaring 8:13 bevat die UBS ${ }^{4 c o r r}$-teks byvoorbeeld 'n lesing wat soos volg vertaal kan word: 'Ek het 'n arend gesien wat hoog in die lug vlieg' (outeur se eie beklemtoning). Die 2020-vertaling lui egter: 'Ek het 'n engel gesien wat hoog in die lug vlieg' (outeur se eie beklemtoning), met die voetnoot: 'Op grond van sterk manuskripgetuienis en die inhoud van Openbaring word die lesing "engel" hier gevolg.'

1.Die wêreldwye gebruik is om na die teksuitgawes van die Wêreldbond van Bybelgenootskappe as die UBS-teks te verwys na aanleiding van die Engelse benaming United Bible Societies. Hierdie gebruik word ook in hierdie artikel gevolg. 


\section{Verhouding tussen die bronteks en die ontvangertaal}

Die vertaalbeleid wat deur die Loodskomitee (2005: Vertaalopdrag, art. 2.1) geformuleer is, bepaal dat die vertaling intertekstueel koherent moet wees. Hierdie norm hou, onder meer, in dat literêre vorms en strukture, beelde en metaforiese taal, indien dit nie tot misverstand in die doeltaal sal lei nie, behou word. Intertekstuele koherensie vereis onder meer dat onderskei word tussen taalkenmerke en tekskenmerke van die brontaal sowel as die ontvangertaal.

\section{Taal- en tekskenmerke}

In die vertaling is tussen die taal- en tekskenmerke van die brontaal onderskei. Taalkenmerke is daardie elemente in die teks wat eie is aan die Hebreeuse, Aramese of Griekse taal en wat slegs 'n grammatikale funksie het. So byvoorbeeld is die gewone woordorde in Hebreeus (werkwoord, subjek, objek, indirekte objek) 'n taalkenmerk. In Grieks word hierdie sinsfunksies weer met naamvalle aangedui, terwyl dit in Afrikaans met woordorde gedoen word (Loodskomitee 2005: Vertaalopdrag, art. 2.1).

Johannes 8:31 kan as voorbeeld dien. Die Grieks lui ’E $\lambda \varepsilon \gamma \varepsilon v$

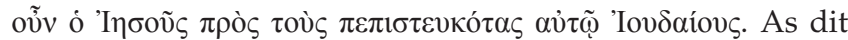
woord vir woord oorgesit moet word, sal dit wees: 'Hy het gesê Jesus aan die wat geglo het in Hom Jode.' Met so 'n vertaling word die Griekse woordorde net so oorgeneem sonder inagneming van die taalkenmerke wat eie is aan Afrikaans. Daarom is die taalkundig korrekte vertaling: 'Toe het Jesus vir die Jode wat in Hom geglo het, gesê ...'. Taalkenmerke word immers nie in vertaling behou nie, want dit moet deur die taalkenmerke van die ontvangertaal vervang word.

Tekskenmerke, daarenteen, is van betekenisbelang en word so ver as moontlik in die vertaling weerspieël. Wanneer die gewone woordorde byvoorbeeld in die bronteks gewysig of omgekeer word ter wille van beklemtoning, word dit 'n tekskenmerk, en moet dit ook in die vertaling beklemtoon word.

'n Voorbeeld van 'n tekskenmerk wat die vertaling beïnvloed,

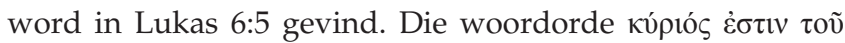

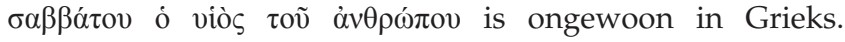

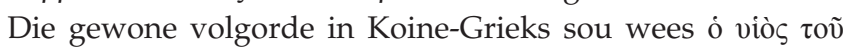

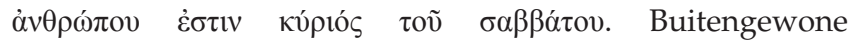
woordorde, ook bekend as die styltegniek hiperbaton, word in Grieks ter wille van beklemtoning gebruik (Jordaan 2014:169-170). Die beklemtoning in Lukas 6:5 word in die 2020-vertaling weergegee met 'Die Seun van die Mens - Hy is Heer van die Sabbat'.

In aansluiting by laasgenoemde word literêre vorms en strukture, beelde en metaforiese taal behou, tensy dit tot misverstand in die doeltaal kan lei. So word Psalm 23 se metafoor 'Die HERE is my Herder' in die 2020-vertaling behou, en ook die 'aardse tentwoning' van 2 Korinthiërs 5:1. ${ }^{2}$

\section{Mate, gewigte, geldeenhede, range}

In die geval van mate, gewigte en geldeenhede vereis intertekstuele koherensie dat geen transkulturasie sal plaasvind nie. Die Hebreeuse en Griekse benamings word so ver as moontlik in die vertaling behou. Waar vertalers dit wel nodig vind om ter wille van die duidelikheid inligting oor die bronteks of brontaal te gee, word dit in voetnote gedoen (Loodskomitee 2005: Vertaalopdrag, art. 2.1). In Genesis 18:6 sê Abraham byvoorbeeld vir Sara volgens die 2020-vertaling om drie sea meel te knie, gevolg deur 'n voetnoot waarin verduidelik word dat drie sea ongeveer 16 kilogram is. Desgelyks staan daar volgens die 2020-vertaling in Johannes 2:6 dat daar by die bruilof van Kana klipkanne met ' $n$ inhoud van drie metretes gestaan het. Dit word gevolg deur 'n voetnoot wat lui: 'Ongeveer 80 tot 120 liter'.

Dieselfde geld vir range en militêre terme. In die 2020-vertaling van Handelinge 24:22-23 sê Feliks: "“Wanneer Lysias, die chiliarg, aankom, sal ek oor julle saak besluit." Hy het die centurio opdrag gegee om Paulus aan te hou'. In die 2020-proefvertaling van die Nuwe Testament en Psalms: (2014) van die Griekse rangbenaming hekatontarg is in die vertaling behou, maar uit reaksie het dit geblyk dat die lesers dit as té vreemd beleef, en daarom is dit uiteindelik in die finale 2020-vertaling met die Romeine ekwivalent centurio vervang. By chiliarg sowel as centurio word daar in die 2020-vertaling in voetnote verduidelik dat die twee range na Romeinse offisiere verwys wat bevel oor onderskeidelik 1000 en 100 soldate voer.

\section{Implisiete en eksplisiete inligting}

Om as outentieke stem uit die verlede te kommunikeer, is die vertaling so gedoen dat dit sover as moontlik al die funksionele elemente van die bronteks oordra. Dit beteken, onder meer, dat implisiete inligting in die bronteks nie in die vertaling uitgespel word nie, maar dat die fokus op die eksplisiete inligting sal val. Implisiete inligting moet in die bronteks gewoonlik uit die konteks afgelei word. Die 2020-vertalers het probeer om dit in die vertaling net so na te doen. Dit is veral die geval met poëtiese taal (Loodskomitee 2005: Vertaalopdrag, art. 2.1; vgl. ook Du Plooy 2020:1042-1045).

Verder bring die feit dat die vertaling vir ' $n$ ingeligte kerklike publiek bedoel is ook mee dat implisiete inligting nie in die vertaling verwoord hoef te word nie. 'n Eenvoudige voorbeeld kom in 1 Korintiërs 5:1 voor waar die 1983-vertalers die implisiete agtergrond van die onsedelikheid in die gemeente deel van die vertaling gemaak het: 'dat ' $n$ man en sy stiefma as man en vrou saamleef'. Die 2020-vertaling hou egter bloot by die eksplisiete mededeling van die bronteks: 'dat ' $n$ man met sy vader se vrou saamleef'. Ook Romeine 1:17 word in die 1983-vertaling 'verduidelikend' vertaal: 'In die evangelie kom juis tot openbaring dat God mense van hulle sonde vryspreek enkel en alleen omdat hulle glo.' Die 2020-vertalers het hulle egter daarvan weerhou om implisiete inligting in die vertaling eksplisiet te maak, en het vertaal: 'Want daarin word geopenbaar dat die geregtigheid van God geheel en al op geloof berus.' 
Indien die vertalers dit wel nodig vind om implisiete inligting uit te spel, word dit in voetnote gedoen. Johannes 3:3 dien as voorbeeld. In die 2020-vertaling sê Jesus vir Nikodemus: 'As iemand nie van bo gebore word nie ...'. Daarby is 'n voetnoot:

In die bronteks word 'n dubbelsinnige woord gebruik [äv $\omega \theta \varepsilon v$ ] wat sowel 'van bo' as 'weer' kan beteken, en in Joh 3:4 verstaan Nikodemus dit as 'weer', maw 'n tweede aardse geboorte.

\section{Teksstruktuur}

Die vertalers het probeer om die teksstruktuur van die bronteks sover as moontlik te behou. Dit is gedoen deur die styl van die bronteks op retoriese, sintaktiese en leksikale vlak in die vertaling te reflekteer sonder om sinvolheid en verstaanbaarheid op te offer. Daarmee het hulle die vertaalbeleid gevolg wat by die aanvang van die projek gestel is (Loodskomitee 2005: Vertaalopdrag, art. 2.1).

Die aanhef van 1 Johannes is 'n sprekende voorbeeld. In die 1983-vertaling is die teksstruktuur van die bronteks feitlik heeltemal opsy geskuif en is vertaal: 'Van die begin af was Hy daar. Ons het Hom self gehoor; ons het Hom met ons eie oë gesien; ja, ons het Hom gesien en met ons hande aan Hom geraak. Hy is die Woord, die Lewe.' Die 2020-vertaling, daarenteen, behou die teksstruktuur van 1 Johannes 1:1 noukeurig, en slaag daarin om dit in betreklik goeie verstaanbare Afrikaans weer te gee:

Wat van die begin af was, wat ons gehoor het, wat ons met ons oё gesien het, wat ons aandagtig bekyk het, en wat ons hande aangeraak het aangaande die Woord van die Lewe, dit verkondig ons aan julle.

\section{Lokale kleur}

Die atmosfeer en 'lokale kleur' van die bronteks is ook so ver as moontlik behou (Loodskomitee 2005: Vertaalopdrag, art. 2.1). Dit het behels dat die vertalers deur woordkeuse, woordorde, modale partikels, sinskonstruksies en uitroepe probeer het om die moderne leser as 't ware terug te verplaas na die leefwêreld van die destydse samelewing. Die gevolg daarvan is dat die vertaling soms ' $n$ argaïese atmosfeer met hom saamdra soos byvoorbeeld Spreuke 28:14: 'Gelukkig is 'n mens wat voortdurend gesag koester vir God! Maar wie sy hart verhard, stort in die ellende. ${ }^{3}$ In die Nuwe Testament kan Romeine 2:1 as voorbeeld van argaïese Afrikaans geneem word: 'Daarom is daar vir jou, o mens wat oordeel, wie jy ook al is, geen verontskuldiging nie.'

Die apostel Paulus het sy briewe geskryf volgens die formele styl van eerste eeu wat beslis vreemd op die oor val vir hedendaagse lesers. ' $n$ Voorbeeld hiervan is die aanhef van die tweede Korintiërbrief: Paulus, 'n apostel van Christus Jesus deur die wil van God, en die broer Timoteus, aan die gemeente van God wat in Korinthe is, saam met al die heiliges in die hele Achaje.

In die 2020-vertaling is hierdie vorm van briefaanhef behou, omdat dit vir moderne lesers nie heeltemal onverstaanbaar is nie, maar hulle tog 'n aanvoeling van die briefskryfkonvensies van die eerste eeu gee.

\section{Nie streng konkordant nie}

Terwyl 'n streng konkordante vertaling in geheel buite die kwessie was, het die vertalers gevind dat dit binne 'n kleiner eenheid tog sinvol is om terme wat ter wille van'n pragmatiese funksie herhaal word, konkordant te vertaal. Dit staan bekend as 'beperkte konkordansie' (Loodskomitee 2005: Vertaalopdrag, art. 2.1). Dieselfde geld vir die herhaling van frases wat bedoel is om te beklemtoon. Beperkte konkordansie is in die 2020-vertaling gevolg deur vaste formules soos die inleidende woorde by profesieë en profete-spreuke (bv. 'So sê die HERE' in Jes 49:7, 8; 25; 50:1) deurgaans op dieselfde wyse te vertaal. Ook die refrein 'Elkeen wat kan hoor, moet luister na wat die Gees aan die gemeentes sê' is in Openbaring 2 en 3 telkens op konkordante wyse weergegee.

Oor die algemeen is Griekse woorde egter nie in die 2020-vertaling streng konkordant vertaal nie, maar na gelang van die konteks waarin dit in die bronteks gebruik is. As

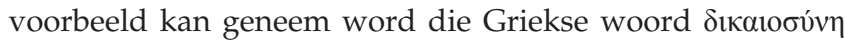
wat in Romeine 1:17 met 'geregtigheid' vertaal is, in Romeine 3:5 met 'regverdigheid', in Romeine 4:3 met 'regverdiging' en in Galasiërs 5:5 met 'vryspraak'.

\section{Verstaanbaarheid van die vertaling}

Die opdrag tot ' $n$ 'goed verstaanbare vertaling' het die voor die hand liggende vereiste gestel dat die vertaling in Afrikaans verstaanbaar moet wees en sal sin maak. Aan hierdie opdrag het die vertalers konsekwent vasgehou.

Die vertalers het egter ook daarmee rekening gehou dat daar plekke in die bronteks is wat inderdaad bedoel was om nie vir alle lesers sonder meer toeganklik te wees nie - iets wat sover as moontlik in die vertaling behou moes word. Die gevolg is dat die teks in sommige gevalle (veral die poëtiese dele) nie onmiddellik duidelik mag wees vir lesers met'n laer tekskompetensie nie. Dit is ook moontlik dat religieuse terme vreemd kan wees vir lesers wat die breër konteks van die leefwêreld waaruit die Bybel kom, nie so goed ken nie. Van der Merwe (2020:900-901) noem die $\mathrm{Ou}$ Testamentiese begrip banvloek as voorbeeld van 'n kultuurspesifieke konsep wat nie in 'n direkte vertaling aangepas kan of behoort te word nie. Die basiese vraag by 'n direkte vertaling is immers: Hoe sou die Bybelse skrywer dit in sy tyd in Afrikaans gesê het? (Van der Merwe 2020:898). Nogtans moes die vertalers toesien dat hulle die vertaling so duidelik as moontlik formuleer. Boonop het die vertalers op plekke waar die vertaling dalk moeilik verstaanbaar is, verduidelikende voetnote by die vertaling as hulpmiddel vir lesers gevoeg

\section{Teikengehoor}

Vir die besluit oor die vlak van verstaanbaarheid van die vertaling was dit vir die 2020-vertalers nodig om die teikengehoor of beoogde lesers byvoorbaat te probeer identifiseer en te omskryf. Met die oog daarop is deeglike marknavorsing gedoen oor die ouderdom en vlak van geleerdheid van die waarskynlike lesers. Omdat die 
verwagte produksietyd van die vertaling op ongeveer 10 jaar gestel is, is Afrikaanssprekendes in die ouderdomsgroep 25 tot 30 jaar met die literêre kompetensie van Graad 12 geskooldes as teikengehoor geïdentifiseer (Loodskomitee 2005: Vertaalopdrag, art. 2.2).

Volgens die versoek van die Kerklike Advieskomitee is die vertaling primêr vir die kerklike publiek bedoel (KABA, 2005:5, art 5). Daarom is die vertaalopdrag spesifiek geformuleer as 'bedoel vir voorlesing en gebruik in eredienste, asook vir kategese, Bybelstudie en privaatgebruik' (Loodskomitee 2005: Vertaalopdrag, art. 1 en 2.2). Die doel van die vertaling is dus nie missionêr van aard nie ${ }^{4}$ en daarom is daar veronderstel dat die teikengehoor minstens oor elementêre kennis van die sosiaal religieuse wêreld van die Bybel beskik. Die aard van die 2020-vertaling vereis in ieder geval sodanige kennis. As hulpmiddel vir Bybellesers is die vertaling wel van talle voetnote en 'n uitgebreide woordelys voorsien waarin die minder algemene Bybelse terme kortliks verduidelik word.

\section{Taal en taalregister}

Die Loodskomitee het dit vooraf duidelik gestel dat die taalmedium natuurlike Afrikaans moet wees in 'n taalregister wat pas by die inhoud en aard van die Bybel (vgl. Du Plooy 2020:1036). Hiermee word bedoel dat die taalregister nie moet verplat soos wat soms die neiging is in sogenaamde 'common language' vertalings nie (Loodskomitee 2005: Vertaalopdrag, art. 2.2).

Die oorspronklike taalregister van elke afsonderlike eenheid in die teks bepaal in 'n hoë mate die register van die doeltaal. Die implikasie hiervan is dat daar nie deurgaans 'n enkele (hoë) register in die vertaling gehandhaaf word nie, maar dat die sosiale stand van Bybelfigure, asook hulle onderlinge verhoudings hulle spreekwyse en dus ook die taalregister bepaal.

Dit is veral sigbaar in die 'jy en jou'-vertaling en die ' $u$ 'vertalings. In Grieks word die voornaamwoord $\sigma u ́$ as aanspreekvorm vir die tweede persoon gebruik, ongeag of dit as 'n hoflike, eerbiedige aanspraak bedoel is (soos die Afrikaanse ' $u$ ') of as 'n gemeensame, oneerbiedige aanspraak (soos die Afrikaanse 'jy' en 'jou'). Die vertalers moes dus telkens uit die konteks aflei of hulle met ' $u$ ' moet vertaal of met 'jy' en 'jou'. So het hulle in Lukas 22:9 die dissipels se vraag aan Jesus vertaal met 'Waar wil U hê moet ons voorbereidings tref?', en die Fariseërs se vraag aan Hom in Lukas 22:70 met 'Is jy die Seun van God?'

Die vertaling se taalregister is verder beperk deur die liturgiese gebruik waarvoor dit bedoel is. Die vertaling moet bruikbaar wees in die kerke. Daarom is kru taal nie weergegee nie. 1 Samuel 24:4, waarin vertel word dat Saul 'sy voete bedek' het, dien as voorbeeld. Hierdie uitdrukking beteken bloot dat, om dit so te stel, Saul hom gaan ontlas het. Die

\footnotetext{
4.Die 1983-vertaling daarenteen is vir ' $n$ wyer leserskring bedoel. Vergelyk die verklaring in die voorwoord van die 1983-vertalers wat lui dat dit ' $n$ vertaling is waarin 'Afrikaanssprekendes aangespreek word, buite en binne die kerk, in die erediens en in huislike gebruik, in ons teenwoordige situasie en tyd'.
}

2020-vertalers het egter, om kru en onvanpaste taal in die teks te vermy, verkies om die Hebreeuse uitdrukking 'voete bedek' te behou met 'n voetnoot ter verduideliking daarby.

Die opdrag was dat die vertaling 'n keurige, stilisties goedversorgde en helder Afrikaanse teks moes wees (Loodskomitee 2005: Vertaalopdrag, art. 2.2). Daarom het die vertalers hulle daarvan weerhou om slengtaal, modewoorde en mode-segswyses in die vertaling op te neem. Ten einde die Afrikaans in die vertaling keurig en stilisties te versorg, het die vertalers die werkswyse gevolg dat daar by elk van die boekspanne en uiteindelik in die redaksionele komitees nasionaal erkende taalkundiges en letterkundiges gedien het. Die taalkundige en literêre adviseurs het bydraes van onskatbare waarde gelewer (vgl. De Wet 2020:1016-1018; Du Plooy 2020:1033-1037).

\section{Enkele noemenswaardighede Godsname}

Soos versoek deur die GKSA, is die Verbondsnaam JHWH waarmee God Hom in die Ou Testament bekendstel, in die 2020-vertaling met HERE vertaal (vgl. Van Rooy 2020b:936-940). Ook die ander Godsname is elkeen sover as moontlik op konkordante wyse vertaal. Om enkele bekende Godsname te noem: êlohim is konsekwent met 'God' vertaal; el sjaddai met 'God, die Almagtige' en JHWH tsewa-oot met 'Die HERE, Heerser oor alle magte' (33/53-vertaling: 'HERE van die leërskare' $).{ }^{5}$

\section{Messiaanse verwysings in die Ou Testament}

Messiaanse verwysings in die $\mathrm{Ou}$ Testament word in die 2020-vertaling met 'n voetnoot aangedui, byvoorbeeld die voetnoot by Jesaja 53:1-12 wat sê dat die verse 'n heenwysing na Christus bevat. Dit sluit die dienskneg in wat Jesaja 53:11 genoem word. Die Messiaanse aard van hierdie dienskneg word in die 1993/1953-vertaling aangedui deur die woord 'Kneg' met 'n hoofletter te begin. In die Hebreeuse teks is daar egter nie' $n$ onderskeid tussen hoof- en kleinletters nie. In navolging van die Hebreeuse bronteks het die 2020-vertalers die woord dienskneg dus net in kleinletters geplaas, met die vermelde voetnoot daarby wat sê dat dit 'n Messiaanse heenwysing is.

Uit die kerke het daar egter besware gekom deur lesers wat daarop aangedring het dat sulke Messiaanse heenwysings steeds met 'n aanvangshoofletter gedruk moet word. Die Bybelgenootskap het aan hierdie versoek toegegee deur, naas die gewone uitgawe, ook 'n sogenaamde Hoofletteruitgawe van die 2020-vertaling te maak. Gevolglik lui Jesaja 53:11 in die Hoofletteruitgawe: 'My Dienskneg sal Hom as 'n regverdige betoon aan baie.' Die teks is identies aan die gewone uitgawe van die 2020-vertaling. Al verskil is dat die Hoofletteruitgawe, benewens die voetnote in die teks, ook 'n hoofletter gebruik om Messiaanse verwysings in die Ou Testament aan te dui. ${ }^{6}$

5.Vir'n meer uitvoerige bespreking van die vertaling van die name vir God, vergelyk Van Rooy (2020b:936-940).

6 .Vir' $n$ meer uitvoerige bespreking van die vertaling van Messiaanse tekste in die Ou Testament, vergelyk Van Rooy (2020b:940-942). 


\section{Die Deuterokanonieke boeke}

Ter wille van die Afrikaanse lesers van die Rooms-Katolieke Kerk is daar ook 'n derde uitgawe van die 2020-Bybel - een met die Afrikaanse vertaling van die $\mathrm{Ou}$ Testamentiese Apokriewe, oftewel die Deuterokanonieke Boeke wat tussen die teks van die Ou en die Nuwe Testament bygevoeg is. Hierdie artikel is egter nie op 'n bespreking van die Deuterokanonieke boeke in die 2020-vertaling gerig nie. Vir 'n vollediger bespreking daarvan kan die artikels van Johann Cook (2020) en Gert Steyn (2020) geraadpleeg word.

\section{Evaluering}

Samevattend kan gesê word dat die Loodskomitee met die vertaalopdrag wat hulle aan die begin van die projek gestel het, die 2020-vertalers voor 'n moeilike taak gestel het. Die vertalers het egter met groot toewyding by die vertaalopdrag gehou. Die manier waarop hulle die vertaling vertolk en toegepas het, het op gebalanseerde wyse aan sowel bronteksgetrouheid en verstaanbaarheid reg laat geskied. Wat tot die suksesvolle hantering bygedra het, is die feit dat tussen taalkenmerke en tekskenmerke van die brontaal sowel as die ontvangertaal onderskei is. Verder het hulle die lokale kleur van die bronteks bewaar deur tipies kultureel historiese verskynsels soos mate en gewigte nie op transkulturele wyse te probeer vertaal nie, maar die Hebreeuse en Griekse terme te behou. Sodoende is die eksotiese karakter van 'n antieke teks in die 2020-vertaling bewaar. Deur die taal en taalregister by 'n voorafbepaalde teikengehoor aan te pas, is die produk 'n geloofwaardige vertaling, maklik verstaanbaar en met 'n gepaste Bybelse waardigheid. Die gevolg is dat die 2020-vertalers Abraham inderdaad Afrikaans laat praat het -'n keurige, stilisties goedversorgde en helder Afrikaans.

\section{Erkenning \\ Mededingende belange}

Die outeur verklaar dat daar geen finansiële of persoonlike verbintenis is met enige party wat haar nadelig kon beïnvloed in die skryf van hierdie artikel nie.

\section{Outersbydrae}

G.J.C.J. was die enigste outeur betrokke by die skryf van die artikel.

\section{Etiese oorwegings}

Hierdie artikel volg alle etiese standaarde vir navorsing.

\section{Befondsing}

Hierdie navorsing het geen spesifieke toekenning ontvang van enige befondsingsagentskap in die openbare, kommersiële of nie-winsgewende sektore.

\section{Data beskikbaarheid}

Die outeur bevestig dat die data wat die bevindings van hierdie studie ondersteun, beskikbaar is in die artikel.

\section{Vrywaring}

Die sienings en menings wat in hierdie artikel uitgedruk word, is dié van die outeur en weerspieël nie noodwendig die amptelike beleid of posisie van enige geaffilieerde verwantskap van die outeur nie.

\section{Literatuurverwysings}

Acta, 1991, Gereformeerde Kerke in Suid-Afrika: Handelinge van die Eerste Algemene Sinode van die Gereformeerde Kerke in Suid-Afrika, gehou te Potchefstroom op 5 Januarie 1991 en volgende dae, Administratiewe Buro, Potchefstroom.

Acta, 1997, Gereformeerde Kerke in Suid-Afrika: Handelinge van die ses-en-veertigste Nasionale Sinode van die Gereformeerde Kerke in Suid-Afrika, gehou te Potchefstroom op 6 Januarie 1997 en volgende dae, besigtig 2 Maart 2021, vanaf https://www.gksa.org.za/pdf/sinode\%20argief/GKSA_Acta_1997.pdf.

Acta, 2009, Gereformeerde Kerke in Suid-Afrika: Handelinge van die eerste Algemene Sinode van die Gereformeerde Kerke in Suid-Afrika, gehou te Potchefstroom op 5 Januarie 2009 en volgende dae asook 29 Junie 2009 en volgende dae, besigtig 3 Junie 2021, vanaf http://gksa.org.za/wp-content/uploads/2021/02/ handelingefinaal.pdf.

Bybelgenootskap van Suid-Afrika: Kerklike Advieskomitee (KABA), 2005, 'Notule', 17 Februarie.

Bybelgenootskap van Suid-Afrika: Loodskomitee vir Direkte Bybelvertaling in Afrikaans (Loodskomitee), 2005, 'Notule: Brontekste OTNT', 15 September.

Cook, J., 2020, 'Vertaalprobleme wat die Deuterokanonieke Boeke oplewer: Jesus ben Sira as voorbeeld', Tydskrif vir Geesteswetenskappe 60(4-1), 983-993.

De Wet, K., 2020, 'Die derde Afrikaanse Kerkbybel: Proses en praktyk van 'n direkte vertaling', Tydskrif vir Geesteswetenskappe 60(4-1), 1007-1027.

Du Plooy, H., 2020, 'Literêre aspekte van die 2020-vertaling van die Bybel in Afrikaans en die bydrae van literêre adviseurs in die vertaalproses', Tydskrif vir Geesteswetenskappe 60(4-1), 1028-1046.

Floor, S.J., 2021, 'Bybelvertalingstipes en nisvertalings: ' $n$ Vergelyking van Afrikaanse vertalings,' voordrag gelewer by 'n Simposium oor Bybelvertaling, NoordwesUniversiteit, 29 Januarie 2021

Jordaan, G.J.C., 2009, 'Textual critcism as basis for exegesis', in A. Du Toit (ed.), Focusing on the message. New Testament hermeneutics, exegesis and methods, pp. 173-215, Protea Book House, Pretoria.

Jordaan, G.J.C., 2014, Die Binnewerk van Antieke Grieks, Potchefstroom Teologiese Publikasies, Potchefstroom.

Jordaan, G.J.C., 2020, 'Die bronteks vir die 2020-vertaling van die Nuwe Testament', Tydskrif vir Geesteswetenskappe 60(4-1), 945-958.

Steyn, G., 2020, 'Vertalers kruis swaarde! Vertaalproblematiek betreffende die swaard as wapen in 1 en 2 Makkabeërs', Tydskrif vir Geesteswetenskappe 60(4-1), 994-1006.

Van der Merwe, C.H.J., 2020, 'Nog 'n vertaling van die Bybel in Afrikaans? Wat maak dit anders?', Tydskrif vir Geesteswetenskappe 60(4-1), 892-911.

Van Rooy, H.F., 2020a, 'Die Hebreeuse grondteks en die 2020-vertaling van die Bybel in Afrikaans', Tydskrif vir Geesteswetenskappe 60(4-1), 912-928.

Van Rooy, H.F., 2020b, 'Die Ou Testament in die 2020-vertaling: Enkele netelige kwessies', Tydskrif vir Geesteswetenskappe 60(4-1), 929-944. 